\title{
PENGEMBANGAN MATA KULIAH HADIS TARBAWI PADA PERGURUAN TINGGI ISLAM
}

\author{
M. Zuhri Abu Nawas ${ }^{\mathrm{a}, 1, *}$, Sapruddin ${ }^{\mathrm{b}, 2}$ \\ ${ }^{a, b}$ IAIN Palopo, Jl. Agatis Balandai, Kota Plaopo, 91914, Indonesia \\ ${ }^{1}$ zuhriabunawas@iainpalopo.ac.id*; ${ }^{*}$ sapruddin@iainpalopo.ac.id
}

\begin{tabular}{l}
\hline ARTICLE INFO \\
\hline Article history: \\
Received : 2020-09-15 \\
Revised : 2020-10-20 \\
Accepted : 2020-12-22 \\
\hline
\end{tabular}

Keywords:

Development,

Tarbawi Hadith

\begin{abstract}
The Tarbawi Hadith material development is a study carried out in the framework of development and component results and approach analysis. This included the development of tarbawi hadith course accessed by integrating and interconnecting science. This research provided inspiration and innovation in the development of constructive scientific quality and presenting reinforcement of learning formulation material as a scientific study program. This study applied an exploratory-descriptive research designed qualitatively. The development of the Tarbawi hadith material required systemic steps and applied by maximizing the sustainable aspect of inter-connectivity between the basic structured of allied subject matter for the aspects of material functions and the methodology of the study of hadith material related to the contemporary religious studies.
\end{abstract}

\section{ABSTRAK}

Kajian Hadis tarbawi adalah studi yang dilakukan dalam rangka pengembangan dan hasil analisis komponen dan pendekatan. Ini termasuk pengembangan mata kuliah hadis tarbawi yang diakses dengan mengintegrasikan dan interkoneksi. Penelitian ini, dapat memberikan inspirasi dan inovasi dalam pengembangan kualitas ilmiah yang konstruktif dan penyajian materi formulasi pembelajaran penguatan sebagai program studi ilmiah. Penelitian ini menggunakan jenis penelitian eksploratif-deskriptif yang dirancang secara kualitatif. Pengembangan mata kuliah hadis tarbawi membutuhkan langkah-langkah sistemik dan dapat diterapkan dengan memaksimalkan aspek keberlanjutan inter-konektivitas antara asas materi pelajaran serumpun yang terstruktur untuk aspek fungsi materi dan metodologi studi materi hadis terkait dengan situasi masalah studi agama kontemporer.

\section{Pendahuluan}

Studi Islam atau Islamic Studies telah mengalami perkembangan di berbagai negara dalam beberapa tahun terakhir. Di Indonesia, studi keislaman banyak dilakukan di berbagai perguruan Tinggi Keagamaan Negeri (PTKI) seperti UIN/IAIN/STAIN, dan juga di Perguruan Tinggi Keagamaan Islam Swasta dan Ma'had Aly. Bahkan dalam perkembangan terakhir, telah dilakukan peletakan batu pertama untuk Universitas Islam Internasional Indonesia (UIII) untuk menjadikan Indonesia sebagai salah satu kiblat studi Islam dunia.

Fokus studi keislaman antara lain: Ulumul Qur'an, Ulumul Hadis, Fiqh, Ekonomi Islam, Pemikiran Islam dan Sejarah Peradaban Islam. Namun pada perkembangannya, kajian terhadap ilmu-ilmu tersebut tidak mengalami perkembangan yang sama. Hal ini memberikan dampak pada karya-karya yang 
lahir pada bidang ilmu tersebut. Sebagai contoh, karya pakar tafsir di Indonesia lebih berkembang dibandingkan para pakar di bidang hadis. Demikian pula pada karya akademik mahasiswa, skripsi, tesis dan disertasi tentang hadis lebih sedikit dibandingkan bidang kajian lainnya.

Mata kuliah hadis adalah mata kuliah wajib di seluruh fakultas pada PTKI. Di Fakultas Tarbiyah, selain terdapat mata kuliah Ulumul Hadis, juga terdapat mata kuliah hadis tarbawi yang menjadi mata kuliah penting bagi mahasiswa Fakultas Tarbiyah. Mata kuliah ini menjadi pendukung kompetensi mahasiswa agar mampu menjadi pendidik yang menguasai dasar-dasar ilmu pendidikan berdasarkan hadis. Alumni Fakultas Tarbiyah selain dituntut memiliki kompetensi pedagogis yang handal sesuai tuntutan UU No. 14 tahun 2005 tentang Guru dan Dosen, maka alumni Fakultas Tarbiyah juga diharapkan memiliki wawasan keislaman dan ketarbiyahan yang luas dan komprehensif (Tim Penyusun 2005).

Salah satu indikator yang dapat digunakan untuk mengukur kemampuan dan wawasan ketarbiyahan mahasiswa Fakultas Tarbiyah adalah penguasaan terhadap mata kuliah Hadis tarbawi (hadis-hadis pendidikan). Dalam mata kuliah ini mencakup tiga komponen, yaitu: al-Qur'an, Ilmu Pendidikan, dan hadis. Untuk mendapatkan pemahaman yang komprehensif dalam mata kuliah ini ketiga komponen diintegrasikan secara cermat dan analitis.

Dalam mata kuliah ini, beberapa tujuan yang ingin dicapai antara lain; pertama, mahasiswa diarahkan untuk mengkaji, menganalisis dan memahami implikasi kependidikan dan nilai-nilai edukatif dari hadis-hadis. Kedua, mahasiswa dapat mengetahui langkah-langkah yang ditempuh untuk melakukan mendapatkan pemahaman yang komprehensif dari suatu hadis. Ketiga, mahasiswa mengetahui dan memahami istilah-istilah yang berkaitan dengan hadis tarbawi seperti: asbâb al-wurûd, sanad, matan, rawi dan kualitas kesahihan hadis. Keempat, mahasiswa mampu menarik kesimpulan tentang konsep pendidikan yang bersumber dari hadis khususnya dalam corak normatif/prenialis (ajaran). Hal tersebut sejalan dengan Kerangka Kualifikasi Nasional
Indonesia (KKNI) yang bertumpu pada sikap, keterampilan umum dan keterampilan khusus (Direktorat Pembelajaran dan Kemahasiswaan 2014).

Namun berdasarkan pengamatan serta evaluasi terhadap sejumlah mahasiswa, penguasaan mahasiswa terhadap hadis tarbawi belum mencapai tingkat yang memuaskan. Salah satu faktor yang dianggap mempengaruhi fenomena ini adalah materi hadis tarbawi yang belum dikemas dan disajikan secara komprehensif. Dalam konteks inilah pengembangan Ilmu Hadis khususnya Hadis tarbawi merupakan sebuah keniscayaan dalam rangka meningkatkan kompetensi dan wawasan alumni khususnya wawasan ketarbiyahan (hadis-hadis pendidikan).

Berdasarkan uraian di atas, tujuan penelitian ini untuk memetakan muatan mata kuliah hadis tarbawi pada berbagai PTKI di Indonesia. selain itu juga, untuk merumuskan peningkatan kompetensi mahasiswa fakultas PTKIN dalam kajian Hadis tarbawi. Penelitian ini dapat menjadi inspirasi untuk melakukan penelitian kandungan tarbiyah hadis-hadis Nabi Muhammad saw.

Secara umum model diartikan sebagai kerangka konseptual yang digunakan sebagai pedoman dalam melakukan suatu kegiatan. Dalam pengertian lain model juga diartikan sebagai barang atau benda sesungguhnya, seperti globe yang merupakan model dari bumi tempat kita hidup. Atas dasar pemikiran tersebut, maka yang dimaksud model belajarmengajar adalah kerangka konseptual dan prosedur yang sistematik dalam mengorganisasikan pengalaman belajar untuk mencapai tujuan belajar tertentu, berfungsi sebagai pedoman bagi perancang pengajaran, serta para dosen dalam merencanakan dan melaksanakan aktivitas belajar mengajar (Majid 2013:13). Menurut Agus Suprijono model pembelajaran adalah pola yang digunakan sebagai pedoman dalam merencanakan pembelajaran di kelas maupun tutorial (Suprijono 2013:45).

Menurut Trianto, model pembelajaran adalah suatu perencanaan atau pola yang dapat digunakan untuk mendesain pola-pola mengajar secara tatap muka di dalam kelas atau mengatur tutorial, dan untuk menentukan material atau perangkat pembelajaran 
termasuk di dalamnya buku-buku, programprogram media komputer dan kurikulum (Trianto 2011:52). Berdasarkan pendapat di atas dapat diketahui bahwa model pembelajaran adalah suatu pola yang digunakan dosen dalam mendesain perangkat pembelajaran seperti buku-buku baik di dalam kelas maupun tutorial.

Menurut Dewey dalam Joice dan Weil model pembelajaran adalah suatu rencana atau pola yang dapat digunakan untuk merancang tatap muka di kelas, atau pembelajaran tambahan di luar kelas dan untuk menajamkan materi pelajaran (Majid 2013:28).

Berdasarkan pendapat para ahli di atas dapat disimpulkan bahwa model pembelajaran adalah suatu teori yang dirancang untuk mendesain proses belajar mengajar di dalam kelas, baik segi alat-alat yang akan dibutuhkan, strategi, dan juga kurikulum guna membantu mahasiswa untuk mencapai tujuan dalam pembelajaran.

\section{Model-model Penelitian Pengembangan}

Pengertian penelitian pengembangan menurut Borg \& Gall adalah suatu proses yang dipakai untuk mengembangkan dan memvalidasi produk Pendidikan (Setyosari 2010:194) Penelitian pengembangan itu sendiri dilakukan berdasarkan suatu model pengembangan berbasis industri, yang temuan-temuannya dipakai untuk mendesain produk dan prosedur, yang kemudian secara sistematis dilakukan uji lapangan, dievaluasi, disempurnakan untuk memenuhi kriteria keefektifan, kualitas, dan standar tertentu. Dari uraian di atas penelitian pengembangan adalah kegiatan yang menghasilkan produk ataupun menyempurnakan produk kemudian diteliti keefektifan dan kelayakan dari produk tersebut.

Model pembelajaran Gerlach dan Ely dikembangkan berdasarkan sepuluh unsur yaitu(Rusman 2013:156):
a. Spesifikasi isi pokok bahasan (specification of content)
b. Spesifikasi tujuan pembelajaran (specification of objectives)
c. Pengumpulan dan penyaringan data tentang mahasiswa (assessment of entering behaviors)

d. Penentuan cara pendekatan, metode dan teknik mengajar (determination of strategy)

e. Pengelompokkan mahasiswa (organization of groups)

f. Penyediaan waktu (allocation of time)

g. Pengaturan ruangan (allocation of space)

h. Pemilihan media/ sumber belajar (selection of resources)

i. Evaluasi (evaluation of performance)

j. Analisis umpan balik (analysis of feedback)

Berdasarkan penjelasan tersebut dapat disimpulkan bahwa metode penelitian dan pengembangan menurut Gerlach dan Ely merupakan metode penelitian yang digunakan untuk menspesifikasi isi pokok bahasan berdasarkan tujuan pembelajaran dan pengumpulan data mahasiswa, penentuan cara, metode dan teknik mengajar, ketersedian ruang dan waktu, evaluasi dan umpan balik mahasiswa.

Model pembelajaran Jeroid E. Kemp terdiri dari delapan langkah yaitu(Rusman 2013:169):

a. Menentukan tujuan pembelajaran umum, yaitu tujuan yang ingin dicapai dalam mengerjakan masing-masing pokok bahasan.

b. Membuat analisis tentang karakteristik mahasiswa. Analisis ini diperlukan antara lain untuk mengetahui, apakah latar belakang pendidikan dan sosial budaya mahasiswa memungkinkan untuk mengikuti program, dan langkah-langkah apa yang perlu diambil.

c. Menentukan tujuan pembelajaran khusus, yaitu tujuan yang spesifik, operasional dan terukur dengan demikian mahasiswa akan tahu apa yang harus dipelajari, bagaimana mengerjakannya, dan apa ukurannya bahwa mahasiswa telah berhasil.

d. Menentukan materi atau bahan pelajaran yang sesuai dengan tujuan pembelajaran khusus.

e. Menentukan strategi belajar mengajar dan sumber belajar sesuai.

f. Koordinasi sarana penunjang yang diperlukan meliputi: biaya, fasilitas, peralatan, waktu dan tenaga. 
g. Mengadakan evaluasi, yaitu untuk mengontrol dan mengkaji keberhasilan program secara keseluruhan.

Berdasarkan penjelasan tersebut dapat disimpulkan bahwa metode penelitian dan pengembangan menurut Jeroid E. Kemp merupakan metode penelitian yang digunakan untuk menentukan tujuan pembelajaran umum dan khusus yang ingin dicapai, menganalisis karakteristik mahasiswa, menentukan materi serta strategi pembelajaran, lalu mengadakan evaluasi.

Model pengembangan ADDIE terdiri atas lima tahapan yaitu: analisis (analysis),perencanaan (design), pengembang an (development), implementasi (implementta tion) dan evaluasi (evaluation)

Berdasarkan penjelasan tersebut dapat disimpulkan bahwa metode penelitian dan pengembangan menurut ADDIE merupakan suatu metode yang menghasilkan suatu produk yang harus melalui beberapa tahapan agar produk yang dihasilkan berkualitas baik, bermanfaat dan dapat digunakan dalam kegiatan pembelajaran

\section{a. Studi Hadis di Perguruan Tinggi Islam}

Dinamika studi hadis di PTKI berjalan dinamis. Menurut Suryadi bahwa setelah nomenklatur baru, studi hadis telah memiliki prospek untuk dikembangkan di masa depan di Indonesia. Adapun solusi yang diberikan adalah untuk mengintegrasikan kembali studi Al-Qur'an dan studi hadis ke dalam studi Tafsir Hadis dan untuk memisahkan dua bidang hanya di tingkat pascasarjana dan menciptakan konsorsium Ilmu Hadis (Suryadilaga 2015). Peran konsorsium ini perlu ditingkatkan. Peran konsorsium ini perlu ditingkatkan. Konsorsium dosen-dosen hadis dipersatukan dalam organisasi ASILHA (Asosiasi Dosen Ilmu Hadis) yang diketuai oleh Dr. Muhammad Fatih Suryadilaga, dosen UIN Sunan Kalijaga Yogyakarta sekaligus sebagai Ketua Program Studi Ilmu Hadis di Fakultas Ushuluddin UIN Sunan Kalijaga Yogyakarta.

Menurut Muhammad Alfatih Suryadilaga bahwa terdapat karakteristik khas yang berbeda antara studi hadis dan studi al-Qur'an. Keilmuan berada pada program studi tafsir hadis yaitu Ilmu Al-Qur'an dan Tafsir, serta Ilmu Hadis. Tujuan tersebut dalam upaya meningkatkan keilmuan kedua bidang tersebut pada PTKIN. Sehingga prodi ilmu hadis direspon positif dan memunculkan ragam studi hadis yang berkembang di PTKIN dikaji secara kontekstual dan bahkan living hadis(Suryadilaga 2015). Diperlukan upaya yang lebih serius agar Prodi Ilmu Hadis diminati dan melahirkan keunggulan di lingkungan PTKI.

Dari hasil penelitian oleh Qibtiyatul Maisaroh bahwa ada tiga model dalam ilmu hadis yaitu model romantisme konstruktif, model historis dan model epistemologi. Model tersebut dipengaruhi oleh beberapa konteks yang mengitarinya mulai dari pergeseran madzhab sampai penggantian status dari IAIN ke UIN serta kerjasama dengan kampus Umum. Serta masuknya literasi berbahasa asing dan pemikiranpemikran tokoh dari barat dan berorientasi di Perguruan Tinggi (Qibtiyatul Maisaroh 2017). Model kajian hadis harus terus dikembangkan seiring dengan perubahan sosial yang berjalan di era disrupsi saat ini.

\section{b. Konsep Metode yang Dikembangkan}

Supriyono mendefinisikan metode pembelajaran adalah pola yang digunakan sebagai pedoman dalam merencanakan pembelajaran di kelas(Supriyono 2009:5). Dari pendapat tersebut dapat diketahui bahwa metode pembelajaran pola atau cara yang dilakukan sebagai pedoman dalam perencanaan pembelajaran yang dilakukan di kelas.

Joy berpendapat bahwa pembelajaran adalah suatu perencanaan atau suatu pola yang digunakan sebagai pedoman dalam merencanakan pembelajaran di kelas atau pembelajaran dalam tutorial dan untuk menentukan perangkat- perangkat pembelajaran termasuk di dalamnya bukubuku, film, komputer, kurikulum, dan lainlain. Joy menyatakan bahwa setiap model pembelajaran mengarahkan kita ke dalam mendesain pembelajaran untuk membantu peserta didik sedemikian rupa sehingga tujuan pembelajaran tercapai (Trianto 2011:5). Berdasarkan pendapat di atas, penulis menyimpulkan metode pembelajaran adalah langkah-langkah dan cara yang digunakan dosen dalam menyajikan pembelajaran dari awal sampai akhir secara khas untuk mencapai tujuan pembelajaran di kelas. 
Model pembelajaran merupakan landasan praktik pembelajaran hasil penurunan teori psikologi pendidikan dan teori belajar yang dirancang berdasarkan analisis terhadap implementasi kurikulum dan implikasinya pada tingkat operasional kelas, model pembelajaran dapat diartikan pula sebagai pola yang digunakan untuk penyusunan kurikulum, mengatur materi, dan memberi petunjuk kepada dosen kelas(Suprijono 2013:45-46). Sesuai dengan pendapat di atas dapat diketahui bahwa metode pembelajaran yang digunakan harus sesuai dengan tujuan yang akan di capai, bahan yang akan diberikan, waktu dan perlengkapan yang tersedia, kemampuan dan banyaknya murid, kemampuan dosen mengajar, sehingga dapat disesuaikan dalam pemilihan metode pembelajaran yang sesuai dengan keseluruhannya dan tidak menyulitkan dosen dan mahasiswanya dalam proses belajar mengajar sehingga bisa tercapai tujuan yang diinginkan.

Pembahasan pada penelitian ini difokuskan pada beberapa aspek, antara lain:

1. Implementasi pembelajaran mata kuliah hadis tarbawi dan muatannya pada PTKI yang dipilih.

2. Pembahasan tawaran solusi peningkatan hasil pembelajaran mata kuliah hadis tarbawi, baik melalui perbaikan muatan/isi, metode pembelajaran, media pembelajaran atau pada lingkungan pembelajaran.

\section{Metodologi Penelitian}

Penelitian ini merupakan penelitian pengembangan yang menghasilkan produk berupa media pembelajaran. Dengan tujuan penelitian ini untuk mengembangkan mata kuliah hadis tarbawi pada perguruan tinggi Islam, maka mengadaptasi model pengembangan ADDIE yang terdiri dari lima tahapan yang meliputi analisis, desain pengembangan, implementasi dan evaluasi (Mulyataningsih 2012:183).

Adapun langkah penelitian pengembangan ADDIE dalam penelitian ini jika disajikan dalam bentuk bagan adalah sebagai berikut:

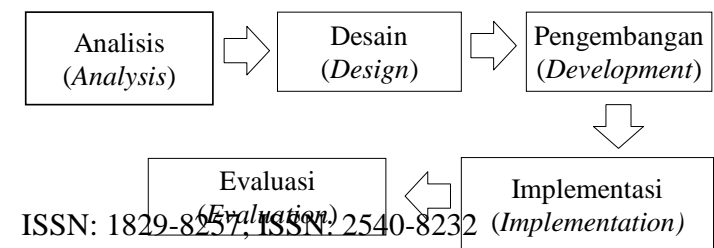

Gambar.1 Bagan langkah penelitian

Penelitian ini dilaksanakan di Universitas Islam Negeri (UIN) Alauddin Makassar, Institut Agama Islam Negeri (IAIN) Parepare, dan IAIN Bone pada bulan juni sampai November 2019. Subjek penelitian ini adalah dosen mata kuliah Tafsir Tarbawi dan mahasiswa Fakultas Tarbiyah di masingmasing Institusi.

Teknik Pengumpulan data dengan wawancara secara mendalam dengan responden, angket, serta tes. Data yang diperoleh adalah terkait mata kuliah hadis tarbawi dilakukan mahasiswa saat perkuliahan berlangsung.

\section{Hasil dan Diskusi}

\section{Referensi Pembelajaran Hadis tarbawi}

Untuk referensi pengembangan mata kuliah Hadis tarbawi adalah sebagai berikut:

Imam Al-Hafizh Ibnu Hajar Al-Asqalani, Fathul Bari Syarah Shahih Al-Bukhari Maktabah Darussalam, Riyadh, Cetakan I, tahun 1418 H/ 1997 M, Edisi Indonesia: Syaikh Abdul Aziz Abdullah Bin Baz, (ed), Ghazirah Abdi Ummah (pen) Fathul Baari Penjelasan Kitab Shahih Al-Bukhari (Fathul Baari jilid 1.- Fathul Baari jilid 2.- Fathul Baari jilid 3.- Fathul Baari jilid 4.- Fathul baari jilid 5.- Fathul Baari jilid 6.- Fathul Baari Jilid 7.Fathul Baari Jilid 8.)

Abdul Majid Khon. Hadis tarbawi: HadisHadis Pendidikan. Prenadamedia Group, 2012. Burhanul Islam Al-Zarnuji, Ta'limul Muta'allim Tariq Al-Ta'allum ( تعليم المتعلم طريق (التعلم), Abdul Kadir Aljufri (ed), Surabaya: mutiara ilmu, 2009. Peta Konsep Mata Kuliah Hadis tarbawi 


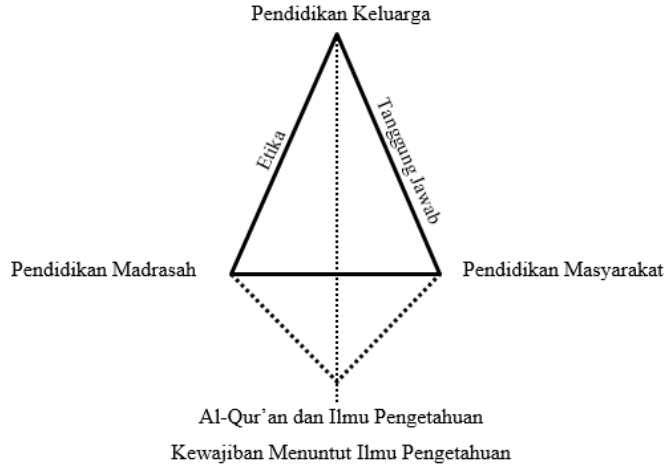

Gambar 2. Peta Konsep Matakuliah Hadis tarbawi

\section{Muatan Matakuliah Hadis di PTKI}

Pengembangan materi ajar atau mata kuliah Hadis tarbawi diperlukan langkahlangkah sistemik dan bersifat aplikatif dengan cara; (1) Memaksimalkan pada aspek kesinambungan interkonektifitas antar materi mata kuliah serumpun dan materi mata kuliah antar dan multi disiplin ilmu, utamanya dalam mengantar signifikansi kajian kehadisan dengan materi bidang program studi yang sedang digeluti oleh mahasiswa; (2) memaksimalkan penugasan mandiri dan terstruktur untuk memfungsikan substansi materi dan metodologi kehadisan dalam capai domain pembelajaran; dan (3) memberikan keluasan dan kesempatan bagi mahasiswa untuk mengkaji sebuah materi hadis yang dianggap sangat dibutuhkan dan terkait dengan mengkaji sebuah materi hadis tarbawi yang dianggap sangat dibutuhkan dan terkait dengan situasi masalah-masalah studi keagamaan kontemporer

Menurut Ahmad Fattah dan Benny alFadzy, Pemahaman Hadis Burhan al-Zarnuji dalam kitab Ta'lîm al-Muta'allim menemukan bahwa Burhan al-Zarnuji memiliki perspektif sufistik dalam memahami hadis. Pemahaman tersebut dapat dikembangkan secara kontekstual sehingga relevan dengan dinamika masa kini(Fattah and al-Fadzy 2016).

\section{Penerapan pembelajaran Hadis tarbawi}

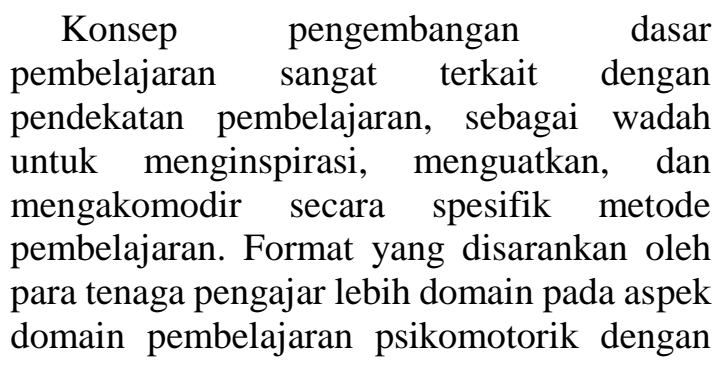

mempertimbangkan fleksibilitas dan akuntabilitas keilmuan, sehingga penyajian materi ajar dikembangkan dengan model dan strategi pembelajaran yang variatif sesuai dengan kebutuhan dan pemenuhan keilmuan program studi. Sistem persentase penyajian dari materi ajar pada RPS dapat saja dirumuskan pada sub-sub bahasannya, namun eksistensi pengkajian hadis disesuaikan dengan tingkat efektivitas dan efisiensi kondisi dan validasi keilmuan program studi yang bersangkutan.

Upaya strategis yang dikembangkan oleh tenaga pengajar atau pengampuh mata kuliah hadis tarbawi adalah dengan melakukan klasifikasi terhadap kebutuhan keilmuan pada masing-masing Program studi tertentu. Kemudian menjabarkan secara sistematik, aplikatif, dan kompetitif dalam ranah progam studi. Format pengembangan bahan ajar disajikan ke dalam RPS perkuliahan dengan menggunakan strategi presentasi penyajian berdasarkan kemampuan, kebutuhan, dan kondisi pemahaman dasar-dasar ilmu hadis, yang didukung oleh akurasi validasi terhadap indikator penilaian untuk pemenuhan domain pembelajaran.

Upaya pengembangan dalam memahami Hadis tarbawi dan metodologi bagi mahasiswa akan lebih komprehensif dan mampu dikembangkan format konstektualitas materi ajar yang disajikan apabila tetap harus memperhatikan beberapa prinsip metodologi, sebagai berikut:

1. Prinsip ideologi

2. Prinsip otoritas

3. Prinsip Klasifikasi

4. Prinsip regulasi terbatas

Sebagai wujud kelengkapan dan kesempurnaan bahan ajar oleh tenaga pengajar Hadis tarbawi dalam lingkup IAIN Parepare, maka strategis penyampaian bahan ajar dikembangkan dengan pola-pola penyederhanaan konsep materi ajar, namun dalam taraf pengaplikasiannya di dalam ruang kelas diperlukan upaya maksimal agar pemanfaatannya terformat secara komprehensif dan berkesinambungan. Dikalangan para pengajar dominan menekankan pada pemenuhan aspek teoritik dan praktik secara bersama-sama.

Penyampaian bahan ajar oleh tenaga pengajar pengampuh mata kuliah Hadis 
tarbawi menggunakan beberapa strategi, sebagai berikut; (1) Strategi urutan penyampaian simultan, yaitu tenaga pengajar menyampaikan materi pembelajaran lebih daripada satu, maka menurut strategi urutan penyampaian simultan, materi secara keseluruhan disajikan secara serentak, baru kemudian diperdalam satu demi satu atau lebih dikenal dengan istilah metode global; (2) strategi urutan penyampaian suksesif, yakni tenaga pengajar menyampaikan materi pembelajaran lebih daripada satu, maka menurut strategi urutan penyampaian suksesif, sebuah materi secara sistematis disajikan secara mendalam, kemudian secara berurutan menyajikan materi berikutnya secara mendalam pula; (3) strategi penyampaian fakta, yakni tenaga pengajar menyajikan materi pembelajaran termasuk jenis kasus-kasus yang terjadi yang merebak di masyarakat atau dalam konteks kekinian; (4) strategi penyampaian konsep, yakni materi berupa definisi atau pengertian. Tujuan mempelajari konsep adalah agar mahasiswa paham, dapat menunjukkan ciri-ciri, unsur, membedakan, membandingkan, menggeneralisasi, dan seterusnya; (5) strategi penyampaian materi pembelajaran prinsip, termasuk materi pembelajaran jenis prinsip adalah dalil, rumus, hukum (law), postulat, teorema, dan sebagainya; dan (6) strategi penyampaian prosedur, tujuan mempelajari prosedur adalah agar peserta didik dapat melakukan atau mempraktikkan prosedur tersebut, bukan sekedar paham atau hafal. Termasuk materi pembelajaran jenis prosedur adalah langkah-langkah mengerjakan suatu tugas secara struktural dan sistematik, baik secara individu maupun kelompok.

\section{Pemahaman Mahasiswa dalam kajian Hadis tarbawi}

Kompetensi perkuliahan menunjukkan adanya kesinambungan antara materi Hadis tarbawi dengan sedikit pengaplikasian dalam bentuk praktik dan penugasan sudah dapat diterapkan. Meskipun sepenuhnya belum mampu mencapai target ketuntasan belajar secara menyeluruh. Faktor utamanya, ditemukan tiga bentuk penyebab terkait dengan hasil penyajian materi ajar, yakni; (1) faktor keragaman persepsi penyajian materi ajar; (2) ketersediaan literatur bahan pembelajaran yang masih dianggap kurang maksimal oleh sebahagian mahasiswa akibat tingkat kemampuan mahasiswa yang kurang memahami dasar-dasar metodologi Hadis tarbawi secara praktis; (3) tingkat motivasi, inovasi, dan kreativitas mahasiswa dalam menyelesaikan tugas-tugas perkuliahan, utamanya pada saat perampungan Ujian MID Semester dan Ujian Akhir Semester pada setiap semester berjalan.

Pertama, pada faktor keragaman persepsi penyajian materi ajar masih belum tampak adanya perubahan sistematik masih sangat tergantung pada hasil-hasil perencanaan dan rumusan pengampuh mata kuliah, sehingga sangat memberikan pengaruh dalam hasil penilaian dan capaian kompetensi serta ketuntasan pembelajaran masih belum mengakomodir domain pembelajaran secara baik.

Kedua, ketersediaan literatur bahan pembelajaran akibat tingkat kemampuan mahasiswa yang kurang memahami dasardasar metodologi Hadis tarbawi secara praktis. Hal ini pada dasarnya terletak pada upaya strategis materi ajar yang tersajikan karena belum maksimalnya materi pembelajaran dalam mengarahkan mahasiswa kedalam bentuk aplikatif atau praktek metodologi pembelajaran hadis. Namun hal ini dapat dimaklumi akibat penyajian meteri ilmu-ilmu hadis hanya tersajikan kedalam 2 SKS saja atau maksimal 13 kali tatap muka perkuliahan, sehingga untuk mengembangkan materi bahasan kehadisan belum banyak menyentuh ranah aspek kompetensi program studi masing-masing, artinya masih berlaku umum dalam lingkup IAIN Parepare.

Ketiga, tingkat motivasi, inovasi, dan kreativitas mahasiswa dalam menyelesaikan tugas-tugas perkuliahan, pada saat Ujian MID Semester dan Ujian Akhir Semester. Berdasarkan pada rumusan materi ajar yang disajikan, maka membawa dampak pada terciptanya iklim pembelajaran yang dapat mencerminkan hasil evaluatif secara sadar bagi mahasiswa untuk diterapkan dalam proses perkuliahan. Dalam hal ini, maka langkah yang dilakukan dalam upaya mengembangkan materi ajar adalah dengan memberikan keluasan untuk memilih topiktopik tertentu untuk dibahas, didiskusikan, dan utamanya dalam pemberian tugas, namun tetap mempertimbangkan signifikansi sub-sub 
bahasan sebagai komponen pokok kompetensi perkuliahan.

Selain faktor-faktor yang menyebabkan target belajar tidak sesuai, pembelajaran hadis tarbawi dapat meningkatkan atau pun memberikan inspirasi bagi mahasiswa. Seperti yang kemukakan oleh Ammar Munir (Munir 2015) bahwa kajian dapat memberikan inspirasi dan sangat diperlukan dalam konteks pendidikan dan pergaulan. Nurhaeni (Nurheni 2018), Jurusan Tarbiyah Prodi Pendidikan Bahasa Arab juga mengatakan bahwa Hadis tarbawi bukan hanya penting untuk peserta didik dan pendidik tetapi juga penting untuk dunia pendidikan karena Hadis tarbawi mencakup semua persoalan yang dibahas dalam dunia pendidikan terutama pendidikan Islam contohnya mengenai kurikulum dan dasar tujuan pendidikan sehingga sampai kapan pun Hadis tarbawi tidak akan pernah lepas dari yang namanya pendidikan (Tarbiyah).

Hadis tarbawi juga didalamnya mencakup pendidik dan etika peserta didik, kurikulum dan tujuan pendidikan dan lain sebagainya sebab Hadis tarbawi meliputi segala aspek yang mencakup penyelenggaraan pendidikan Islam. Hal ini senada dengan pendapat hasil wawancara salah satu mahasiswi Jurusan Tarbiyah Prodi Pendidikan Agama Islam Ririn Adrianti (Andrian 2018) mengatakan bahwa Hadis tarbawi berpengaruh besar terhadap pendidikan karena hadis merupakan sumber kedua setelah Al-Qur'an.

Menurut Asdar, Jurusan Tarbiyah Prodi Tadris Bahasa Inggris; Hadis tarbawi sangat penting dalam dunia pendidikan karena dengan mengetahui hadis dari suatu pendidikan, kita akan mengetahui konsep belajar dan mengajar dalam Islam, akhlak dalam menuntut ilmu dan adab dalam menyampaikan suatu ilmu. Hadis tarbawi juga mengarahkan kita memahami keislaman dan konsep kependidikan sesuai dengan makna yang terkandung dalam hadis (Asdar 2018).

\section{Kesimpulan}

Pengembangan materi ajar atau mata kuliah Hadis Tarbawi diperlukan langkahlangkah sistemik dan bersifat aplikatif. Relevansi antara materi ajar dan metode pembelajaran pada Perguruan Tinggi Keagamaan Islam Negeri lebih dominan dikembangkan pada aspek teoritis dengan melakukan penguatan kajian kehadisan dalam menempatkan hadis sebagai suatu mata kuliah komprehensif dalam lingkup institusi. Meskipun dalam merencanakan materi ajar masih perlu dilakukan secara bertahap dengan pertimbangan masih adanya keragaman minat, motivasi, dan kemampuan mahasiswa untuk mendalamai dan mengkaji hadis berdasarkan kontektualitas kasus-kasus di masyarakat.

Format yang disarankan oleh para tenaga pengajar lebih dominan pada aspek domain pembelajaran dengan mempertimbangkan fleksibilitas dan akuntabilitas keilmuan. Sehingga penyajian materi ajar dikembangkan dengan model dan strategi pembelajaran yang variatif sesuai dengan kebutuhan dan pemenuhan keilmuan Program Studi. Konsep pengembangan dasar pembelajaran sangat terkait dengan pendekatan pembelajaran, sebagai wadah untuk menginspirasi, menguatkan, dan mengakomodir secara spesifik.

\section{Daftar Pustaka}

Andrian, Ririn. 2018. "Wawanacara Dengan Mahasiswa."

Asdar. 2018. "Wawancara Dengan Mahasiswa."

Direktorat Pembelajaran dan Kemahasiswaan. 2014. "Panduan Penyusunan Capain Pembelajaran Lulusan Program Studi."

Fattah, Ahmad, and Benny al-Fadzy. 2016. "Pemahaman Hadis Burhan Al-Zarnudji Dalam Kitab Ta'lim Mutaaalim." Jurnal Ulul Albab UIN Malang 17(2).

Majid, Abdul. 2013. Strategi Pembelajaran. Bandung: Remaja Rosdakarya.

Mulyataningsih, Endang. 2012. Metode Penelitian Terapan Bidang Pendidikan. Bandung: Alfabeta.

Munir, Ammar. 2015. "Hadis tarbawi Tentang Hadis Tentang Teman Bergaul." Jurnal Shaut Al-'Arabiyah, UIN Alauddin Makassar 3(2).

Nurheni. 2018. "Wawancara Dengan Mahasiswa."

Qibtiyatul Maisaroh. 2017. "Kajian Ilmu Hadis Di Perguruan Tinggi (Studi Atas Karya Tesis Di UIN Sunan Kalijaga Tahun 1990-2010)." Institut Agama Islam Surakarta. 
Rusman, Rusman. 2013. Model-Model Pembelajaran Mengembangkan Profesionalisme Dosen Edisi Kedua. Jakarta: Raja Grafindo Persada.

Setyosari, Punaji. 2010. Metode Penelitian Pendidikan Dan Pengembangan. Jakarta: Kencana.

Suprijono, Agus. 2013. Cooperatif LearningTeori Dan Aplikasi Paikem. Yogyakarta: Pustaka Pelajar.

Supriyono, Agus. 2009. Jenis-Jenis Model Pembelajaran. Yogyakarta: Pustaka Pelajar.

Suryadilaga, Muhammad Alfatih. 2015. "Ragam Studi Hadis Di PTKIN
Indonesia Dan Karakteristiknya: Studi Atas Kurikulum IAIN Bukittinggi, IAIN Batusangkar, UIN Sunan Kalijaga, Dan IAIN Jember." Journal of Qur'an and Hadith Studies, UIN Jakarta 4(2):21547.

Tim Penyusun. 2005. Memetakan Persoalan Perguruan Tinggi Agama Islam. Jakarta: Ditpertais Depag RI.

Trianto, Trianto. 2011. Model Pembelajaran Terpadu. Jakarta: Bumi Aksara.

Note:

No. Handphone/WA: 082291851902 